\title{
Dynamic Economic Load Dispatch of CHP Microgrid Using Improved Particle Swarm Optimization
}

\author{
Surmadhur Pant, Vishal Gupta
}

\begin{abstract}
For the sustainable development and various industrial applications, Combined Heat - Power system offers advantages such as saving of energy, economic as well as environment protection benefits. Paper deal with dynamic economic load dispatch of C-H-P,Micro-Grid (Wind- Energy Conversion system, P-V array), Fuel Cell, Boiler(Waste- Heat), thermal and electrical loads. For this purpose, a nonlinear optimal CHP micro grid model has been built and simulated for the economic function of present power generating resources and to generate the twenty four(24) work schedule with forecasted condition of wind, solar, heat and electrical demand for next 24 hours. The methodology used for finding the solution of model is improved particle swarm optimization. Model has been tested with and without peak valley pricing. Results indicate that cost of the system is effectively reduced with peak valley pricing. The simulated results of the system with improved particle swarm optimization (IPSO) and PSO techniques have been shown and compared. The simulation results indicate that the improved PSO providesimprovised solution as compared to PSO.
\end{abstract}

Index Terms: Microgrid Combine CHP-Heat and Power), Dynamic Economic Dispatch, PSO=particle swarm optimization

\section{INTRODUCTION}

Now-a-days, there is a globalconsent for the integration and development of renewable energy source (RES) such as solar system and windenergy into the existing power system.The beginning of advance Electronics Interface Converters and their control lead to approval of RES. The previous(conventional)design of distribution power transmission system has modified now into Active(present) Distribution Systems and Microgrid. With the advancement of distribution technology, the system [1-5] offers an advance solution for the comprehensive use of RES. Microgrid integrates various distributed energy resources close to consumer site with control and power conversion units. In the microgrid, the economic load dispatch is a major issue discussed in the literature [6]-[7].

The economic load dispatch can be broadly classified as static and dynamic dispatch [8]-[10].SED-The static economic dispatch can manage only one load level at any specific time. However,Static economic dispatch not able to withstand by variation of demanded load due to generated ramp limit. Due to variation in the load demand of

customersand activebehavior of the power systems, the analysis of optimal dynamic missive problem is required to minimize the operational cost.ODD is an addition of static economic-dispatch to analyze the production scenario of the functional units so as to overcome the predictable demand of load over instant of time at minimumcostunder ramp-rate and other constraint.RES are subjected to uncertainty and interruption, which creates difficulty to simplify the Dynamic Economic Dispatch[11].

The network consists of solar and wind energy resources have been developed as economic Load distribution problem for dynamic load distribution. For minimum duration of operation, optimalmodel of economic load dispatch was founded [12]. It measures the risk and to control conventional power system with wind energy conversion systems. Similarly various researchers have modeled the microgrid and optimized the costs of fuel, running and maintenance and installation costs as well as the emission costs. In [13-15], the economic dispatch model (EDM) of micro-grid(MG)allowing for some uncertainties which impacts on the micro-grid economic operations such as energy demand, electricity prices and environmental conditions was represented by single-objective optimal technique. In [16] Particle Swarm Optimization (PSO) method was used to simplify the problem of economic load dispatch in the Micro-Grid. The main advantage of Particle swarm optimization are easy conceptual, simple application, Robust to curb parameters and calculation efficiency[17]. Despite its several advantages, sometimes PSO based solution may confined in Local -minima when deal with complex constrained issuedue to Global and Local seeking capability[18],[19]. Therefore, there is a scope for the implementation of new optimization techniques to find the optimal solution for such problems [20]-[22].

This paper investigates the performance of the combined heat-power (CHP) system, also called distributed generationor cogeneration. It is the synchronized generation of two types of Energy system Electricity and Heat from one fuel source, often natural gas. The capability to producemultiple(two)source of energy offers improved efficiency and thus both environmental benefits and cost savings. Here Improved PSO technique is implemented for the dynamic economic load dispatch of CHP micro-grid. This method eliminates the drawbacks of PSO by adding the chaotic sequences in combination with the linearly declining inertia weights and the crossover operation. Simulation results obtained for PSO and improved PSO based ODD microgrid model have been compared and analyzed in this research work. The Section 2presents the mathematical model of the economic load dispatch problem in CHP microgrid.In section 3, working of particle swarrn optimization (PSO) algorithm is described. Section 4 explains the IPSO algorithm while section 5 represents the simulation results for various cases. lastly, section 6 concludes the paper with scope for future job. 


\section{MATHEMATICAL MODEL OF ECONOMIC LOAD DISPATCH FOR CHP MICROGRID}

The objective of this problem with CHP is to minimize the schedule of every resource and minimization of the operating costs, for the forecasted data of wind and solar energy, heat and electricity demand. The installation cost of wind turbine and photovoltaic (PV) array is not considered in this problem. The running cost of the system considers purchase cost of main- grid power, selling cost of power to the main-grid, the total cost of Natural-Gas obtain by gas boilerand fuel-cell, preservationcost of Wind-Energy Generators, Photovoltaic fuel Cell, Boller (Waste- Heat) and gas boiler. The main objective function expressed as:

$$
\mathrm{F}=\min \sum_{\mathrm{i}=1}^{\mathrm{T}}\left(\mathrm{c}_{\mathrm{ph}}+\mathrm{c}_{\mathrm{se}}\right) \mathrm{P}_{\mathrm{ex}}^{\mathrm{i}} / 2+\frac{\mathrm{c}_{\mathrm{ph}}-\mathrm{c}_{\mathrm{se}}}{2} \cdot\left|\mathrm{P}_{\mathrm{ex}}^{\mathrm{i}}\right|+\mathrm{c}_{\mathrm{gas}} *
$$

$\left(\frac{\mathrm{P}_{\mathrm{fl}}^{\mathrm{i}}}{\eta_{\mathrm{fl}}^{\mathrm{i}}}+\frac{\mathrm{P}_{\mathrm{gb}}^{\mathrm{i}}}{\eta_{\mathrm{gb}}}\right)+\mathrm{P}_{\mathrm{fl}}^{\mathrm{i}} * \mathrm{c}_{\mathrm{fl}} \mathrm{l}_{\mathrm{om}}+\mathrm{P}_{\mathrm{fl}}^{\mathrm{i}} * \mathrm{r}_{\mathrm{fl}}^{\mathrm{i}} * \eta_{\mathrm{hr}_{\mathrm{bl}}} * \mathrm{c}_{\mathrm{bl}} \mathrm{om}_{\mathrm{g}}+\mathrm{P}_{\mathrm{gb}}^{\mathrm{i}} * \mathrm{c}_{\mathrm{gb}}+$

$\mathrm{P}_{\mathrm{wt}}^{\mathrm{i}} * \mathrm{c}_{\mathrm{wt}_{\mathrm{om}}}+\mathrm{P}_{\mathrm{pv}}^{\mathrm{i}} * \mathrm{c}_{\mathrm{pv}_{\mathrm{om}}}(1)$

where,

$T$ : total number of time interval (h);

$P_{e x}^{i} \quad$ :power(KW)transmission between C-H-P and Main-grid if $\mathrm{i}$ interval ( for purchasing power +, selling power -);

$P_{f l}^{i}$ : fuel- cell power(KW)at interval $i$;

$P_{g b}^{i}:$ Gas- boilerpower(KW) at interval $i$;

$P_{w t}^{i}:$ Wind-generatorpower(KW) at interval $i$;

$P_{p v}^{i}$ : Photo-voltaic power(KW)at interval $i$;

$c_{p h}$ : Purchasing PowerTariff((¥/KWh); ) from main grid

$c_{s e}$ : Selling PowerTariff( $\left.¥ / K W h\right)$ to Main grid

$c_{\text {gas }}$ : Natural- gas Tariff ( $¥ / \mathbf{K W h}$ );

$c_{f l_{\text {_om }}}$ : fuel cell (working and maintenance) cost (¥/KWh);

$c_{b l_{\text {_om }}}$ : Gas-boiler(working and maintenance) cost (¥/KWh);

$c_{w t \_o m}$ : wind- generator operation and maintenance cost (¥/kWh);

$c_{p v_{-} o m}$ :photo-voltaic array (PV) cost of operation and maintenance ( $¥ / \mathbf{k W h})$;

$\eta_{f l}^{i}:$ efficiencyof Fuel- cell at interval $i$;

$r_{f l}^{i}$ : ratio of Heat- Electricity forFuel- Cell at interval $i$;

$\eta_{g b}:$ gas boiler efficiency (p.u.);

$\eta_{h r_{-} b l}:$ waste heat boiler efficiency (p.u.);

\subsection{Constraints of the CHP microgrid model}

There are various constraints in the abovementioned mathematical model which are as follows:

\subsubsection{Power Balance Constraint}

The electrical power generation by all the distributed energy resource (DERs) should satisfy the load demand if power generated by sources is more than demand then $P_{e x}^{i}$ will be negative otherwise positive.

$$
P_{e x}^{i}+P_{f l}^{i}+P_{w t}^{i}+P_{p v}^{i}-P_{e l}^{i}=0(2)
$$

\subsubsection{Heat Balance Constraint}

The heat balance equation should be satisfied by gas boiler heat and waste heat boiler recovered through recovery heat boiler.

$$
P_{f l}^{i} * r_{f l}^{i} * \eta_{h r_{-} b l}+P_{g b}^{i}-P_{t h}^{i}=0(3)
$$

2.1.3. Constraints of C-H-P and Main -Grid switching power

C-H-P and Main -Grid switching power should be allowed in permissible limits.

$$
P_{e x}^{\min } \leq\left|P_{e x}^{i}\right| \leq P_{e x}^{\max }
$$

\subsubsection{Power generation capacity constraint}

Each source is allowed to generate power in its specific electrical power capacity.

a) Constraints of Fuel cell $P_{f l}^{\min } \leq P_{f l}^{i} \leq P_{f l}^{\max }$

b) Constraints of Waste Heat Boiler $P_{b l}^{\min } \leq P_{f l}^{i} * r_{f l}^{i} * \eta_{h r_{-} b l} \leq P_{b l}^{\max }$

c) Constraints of Gas Boiler:

$$
P_{g b}^{\min } \leq P_{g b}^{i} \leq P_{g b}^{\max }
$$

\subsubsection{Constraint of Ramp rate limit of fuel cell}

The power generate, $P_{f l}^{i}$ by thefuel $\operatorname{cell}(\mathrm{FC})$ in definiteperiod may not surpass that of previous $\operatorname{period} P_{f l}^{i-1}$ by more than a definite amount $\Delta P_{f l_{-} u p}$, the upper-ramp limit and neither may it be not more than that of the previous period by greater than some amount $\Delta \boldsymbol{P}_{\boldsymbol{f l} \_ \text {down }}$, the Down ramp limit of the fuel cell

$$
\Delta P_{f l \_d o w n} \cdot T \leq P_{f l}^{i}-P_{f l}^{i-1} \leq \Delta P_{f l_{-} u p} \cdot T
$$

where,

$P_{e l}^{i}$ : Demanded electricity at interval $i(\mathrm{~kW})$;

$P_{t h}^{i}:$ demanded heat $(\mathrm{KW})$ at interval $i$;

$P_{\boldsymbol{e x}}^{\min }$ : thelowest value ofC-H-P and Main -Grid switching power $\boldsymbol{P}_{e x}^{\max }$ : the highest power i.eswitching power between CHP and the main grid;

$\Delta P_{f l d d o w n}$ : Fuel-cell(KW) ramp rate Lower-limit;

$\Delta P_{f l \_u p}:$ Fuel-cell(KW) ramp rate Upper-limit ;

$P_{f l}^{m i n}$ : lowest limits of fuel cell $(\mathbf{k W})$;

$P_{f l}^{\max }$ : highest limits of fuel cell $(\mathrm{kW})$;

$P_{b l}^{\min }$ : lowest limit of power for waste heat boiler $(\mathrm{kW})$;

$P_{b l}^{\max }$ : highest limits of waste heat boiler $(\mathrm{kW})$;

$P_{g b}^{\min }$ : lowest limits of gas boiler $(\mathrm{kW})$

$P_{g b}^{\max }$ : highest limit of gas boiler $(\mathrm{kW})$;

\subsection{Constraints of the P-E-M Fuel Cell}

The overall efficiency of P-E-M fuel cell is defined by P-L-R (part load ratio). Therefore, $r_{f l}^{i}$ and $\eta_{f l}^{i}$ are the functionsof $P L R_{i}$. The relation among them is given by following mathematical expressions: 


$$
\text { if } \begin{gathered}
P L R_{i}<0.05 \text {, then } \eta_{f l}^{i}=0.2716 ; r_{f l}^{i} \\
=0.6816
\end{gathered}
$$

when $P L R_{i} \geq 0.05$, then

$$
\begin{aligned}
& \eta_{f l}^{i}=0.9033 P L R_{i}^{5}-2.9996 P L R_{i}^{4}+ \\
& 3.6503 P L R_{i}^{3}-2.0704 P L R_{i}^{2}+0.4623 P L R_{i}^{1}+ \\
& 0.37 \\
& r_{f l}^{i}=1.0785 P L R_{i}^{4}-1.9739 P L R_{i}^{3}+ \\
& 1.5005 P L R_{i}^{2}-0.2817 P L R_{i}^{1}+0.3747(10)
\end{aligned}
$$

\subsection{Peak-valley pricing and peak load shifting}

for reducing pressure on Grid-Peak parameter and understandmaximum economic advantages, the Peak-Valley pricing is used. It is time-based pricing, where supply and demand varying with time. The peak-valley electricity is very important, it is an essential means of obtaining Peak load movement, then confirming the stabilityand economy of the system. it is mainly categories into three section. The purchasing and sale pricing of each duration are listed in Table 1. There are 10-hour for peak period, 10-hour for the valley period and 4-hour for the intermediate period. Result of Peak-Valley pricing on the operational costs of the system are considered in this paper.

Table.1 Peak-Valley power pricing

\begin{tabular}{|l|l|l|l|}
\hline Period & Detail time & Purchase price & Sale price \\
\hline Peak time & $\begin{array}{l}9,12 \\
17,22\end{array}$ & $0.9 ¥ / \mathrm{KWh}$ & $0.5 ¥ / \mathrm{KWh}$ \\
\hline $\begin{array}{l}\text { Intermedia } \\
\text { te time }\end{array}$ & 13,16 & $0.8 ¥ / \mathrm{KWh}$ & $0.4 ¥ / \mathrm{KWh}$ \\
\hline $\begin{array}{l}\text { Valley } \\
\text { time }\end{array}$ & $\begin{array}{l}1,8 \\
23,24\end{array}$ & $0.7 ¥ / \mathrm{KWh}$ & $0.3 ¥ / \mathrm{KWh}$ \\
\hline
\end{tabular}

\section{PARTICLE SWARM OPTIMIZATION (PSO)}

PSO is a population based Stochastic Optimization Technique which was develop by Eberhart and Kennedy in 1995 [23]. It is a Robust-Optimization which is depend on the movement and intellect of swarms searching for food around a search space.The PSO algorithm mimics the foodsearching behaviour of swarmsfor finding the optimal solution. In PSO, the potential solutions are called particles and every particle in search area adjust its "flying" according to airborne experience and flying practice of other particles and attempts to improve its performance. The system is initialized with a populationdata of random solution and findings for optimal solution by updating the solutions through iterations. In this algorithm, the position and the particle velocity are updated by using an operator depend on strength information obtained from the environment which enable the individuals to move towards the better solution.

In, the position and the velocity of $n$-dimensional search space, of ith particle are denoted by $X_{i}=\left(x_{i 1}, \ldots \ldots \ldots \ldots x_{i n}\right)$ and $V_{i}=\left(v_{i 1}, \ldots \ldots \ldots \ldots v_{i n}\right)$, where $\mathrm{n}$ is the dimension which represents the number of parameters. Let components $P_{\text {best_i }}=\left(x_{i 1}^{P}, \ldots \ldots x_{i n}^{P}\right)$ and $G_{\text {best } \_}=\left(x_{i 1}^{G}, \ldots \ldots . x_{i n}^{G}\right)$ is the best location of ithparticle and its adjacent particle neighbors' best position, respectively. The updated velocity and updated position of every particle can bemeasured as follows:

$$
\begin{gathered}
v_{i}^{k+1}=w v^{k}+c_{1} * \operatorname{rand}_{1} *\left(\text { Pbest }_{i}^{k}-X_{i}^{k}\right)+c_{2} * \\
\operatorname{rand}_{2} *\left(\text { Gbest }_{i}^{k}-X_{i}^{k}\right) \\
X_{i}^{k+1}=v_{i}^{k+1}+X_{i}^{k}
\end{gathered}
$$

where, $v_{i}^{k}$ : ith particle velocity at iteration $k ; w$ : Inertia weight factor;C1,C2:co-gnitive and social coefficients; rand $_{1}$, rand $_{2}$ : random number between $[0$ $1] ; X_{i}^{k}$ : position of ith particle at iteration $k$.

Appropriatechoice of inertia weight can provide good link between local exploitation and global exploration andresults less number of iterations to find the bestresult. In order, to improve the convergence characteristics, the inertia weight factor $w$ is chosen to decrease linearly from $w_{\max }$ to $w_{\text {min }}$ as given by Eq. (13).

$$
w=w_{\text {max }}-\left(w_{\text {max }}-w_{\text {min }}\right) * \text { Iter } / \text { Iter }_{\text {max }}
$$

where,Iter $r_{\text {max }}$ : maximum iteration number.

Using the new position $X_{i}^{k+1}$, the $P_{\text {best_i } i}$ and $G_{\text {best_i } i}$ are updated at iteration $\mathrm{k}+1$ using the voraciousselection. The general principle of the algorithm is shown in the Figure 1.

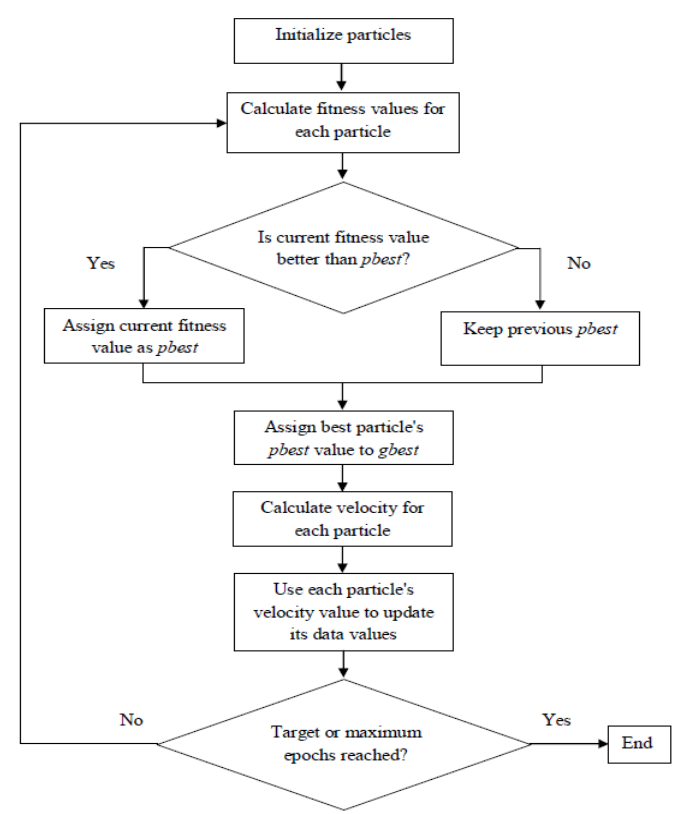

Figure 1. Flowchart of PSO algorithm

\section{IMPROVED PARTICLE SWARM OPTIMIZATION}

The improved PSO utilizes the application of chaotic sequence and crossover operation. Chaos means chaotic behavior that is neverthelessstoicism in nature. It is a phenomenon which takes place in several areas of technology [24-26]. Chaotic sequence uses the mutation situation in differential evolution to update the value. Dynamic systems resembling chaotic nature is the iterator called the logistic map [23], whose general equation is given by

$$
\mathbf{f}_{\mathbf{k}}=\mu * \mathbf{f}_{(\mathbf{k}-1)}\left(\mathbf{1}-\mathbf{f}_{(\mathbf{k}-\mathbf{1})}\right)
$$

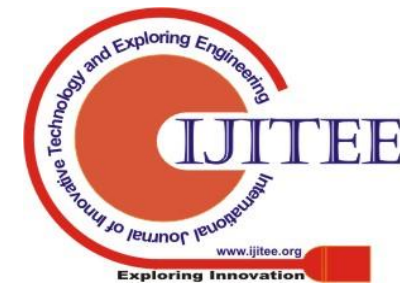


where, $\mu$ is a managing parameter and has a value 27 , and $f_{k}$ is chaotic parameter at $\mathrm{k}$ iteration. Despite the obviousease of this equation, varied behavioris exhibited by solution. System behaviorshowed by (x) is almost changed with the variation .' $\mu$ 'examines whether $f$ is stabilize at a constant size or chaotically act in an random pattern. The system $(\mathrm{x})$ is settled, and shows chaotic behaviors when $\mu=4.0$ and $f_{0} \in$ $\{0,0.25,0.50,0.75,1.0\}$. Figure 2 shows the comparison of inertia weights calculated by PSO and IPSO.

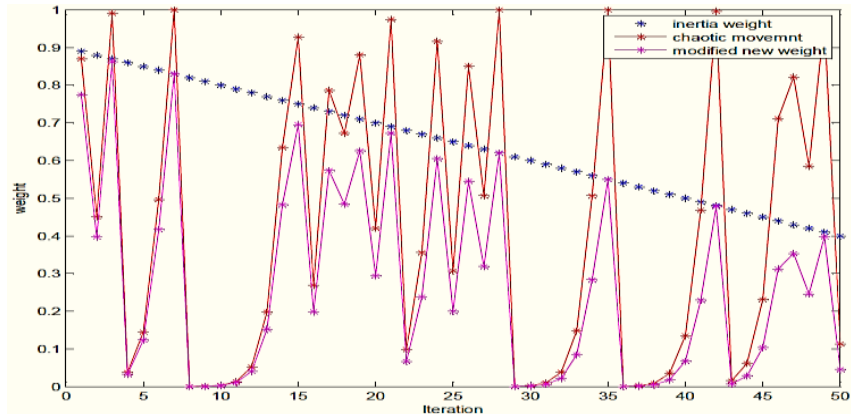

Figure 2. Comparison of weight by IPSO and original PSO.

To increase the exploration of a solution, the crossover operation has been performed in this research work to find better solution that can prevent the premature convergence. the diversity of the solution increases, thereby can explore and make use of promising regions in search space. In crossover operation, updated particle $i$, position i.e. $X_{i}=$ $\left(x_{i 1}, \ldots \ldots \ldots \ldots, x_{i n}\right)$ is mixed with Pbest $_{i}$ particle to produce new vector $\hat{X}_{i}=\left(\hat{x}_{i n}, \ldots \ldots \ldots \ldots \ldots, \hat{x}_{i n}\right)$ as follows:

$$
\hat{x}_{i j}^{k+1}=\left\{\begin{array}{l}
x_{i j}^{k+1}, \text { if } r_{i j} \leq C R \\
x_{i j}^{\text {Pbest }, k}, \text { otherwise }
\end{array}\right.
$$

For $j=1,2 \ldots \ldots \ldots \ldots, n$;

where, $r_{i j}$ is distribution of number with in [0 1].In order to pertain the scenario-based stochastic optimization method to the abovementioned optimization problem, the following steps were implemented in this paper.

Step1: Input each source parameters of C-H-P system, having running parameter, cost parameter.

Step 2: Define the parameter of IPSO algorithm such as particle size, initial\& final Inertia-Weight, acceleration coefficients $\mathrm{C}_{1}, \mathrm{C}_{2}$, crossover rate and maximum number of iteration.

Step 3: Generate PV, wind power, heat load and electric load for twenty four periods of the subsequentday with respect to their location

Step 4: Generate fuel cell power and making up particle; update the variable using equality and inequality constraints if necessary.

Step 5: To Calculate each particle fitness using the objective function, define the P-best and G-best on account of their fitness values.

Step 6: particles velocity are initialise.

Step 7: Updateboth the velocity and the positionof particle by using Eq. 11,12.
Step 8: Generate the new position vector using crossover rate and update the variables using equality and inequality constraints if necessary.

Step 9: To Calculate and compareeach particlefitness to its P-best if it is greater than P-best then change the P-best and update the position. Similarly, compare updated gbest toprevious gbestand if it is improved(greater) over G-best then replace it, update gbest and update the position.

Step 10: Repeat steps 7-9 until Maximum Iteration is reached.

Step 11: Output the optimal value and solution of objective function.

\section{DISCUSSION AND RESULTS OF SIMULATION}

The simulation of the model proposed was carried out in MATLAB/ Simulink. The optimum economic schedule was analyzed fora day with an hour interval for this work. The solar, wind, electrical power demand and heat demand were predicated in an hourly basis for 24 hours. Forecasted curve for power(wind and solar), demand (electricity and heat )were built up for 24 hours andshown in Figure 3 to6. The base values of power were taken $300 \mathrm{~kW}, 200 \mathrm{~kW}, 300 \mathrm{~kW}$ and $150 \mathrm{~kW}$ respectively.

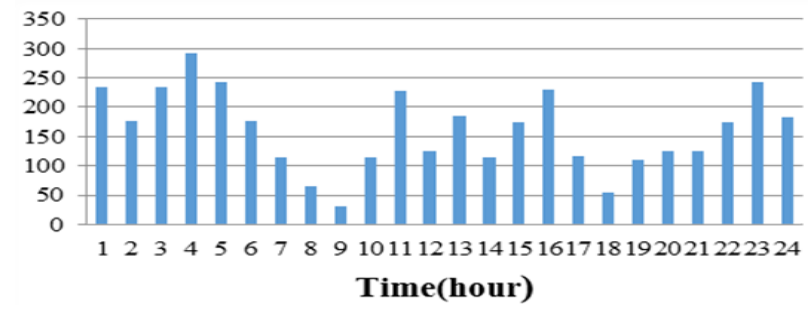

Figure 3. Forecasting curve for wind power generation

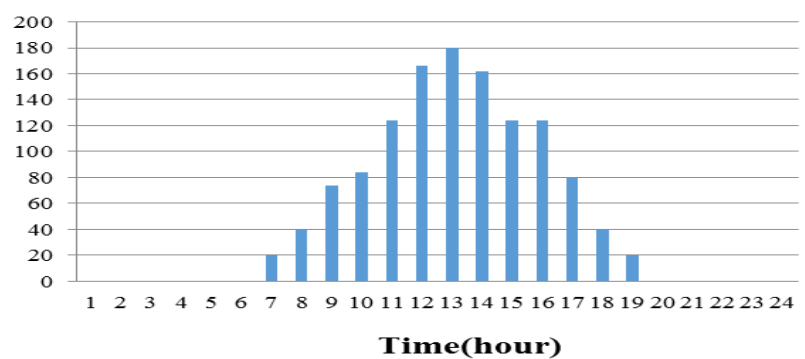

Figure 4. Forecasting curve for solar power generation

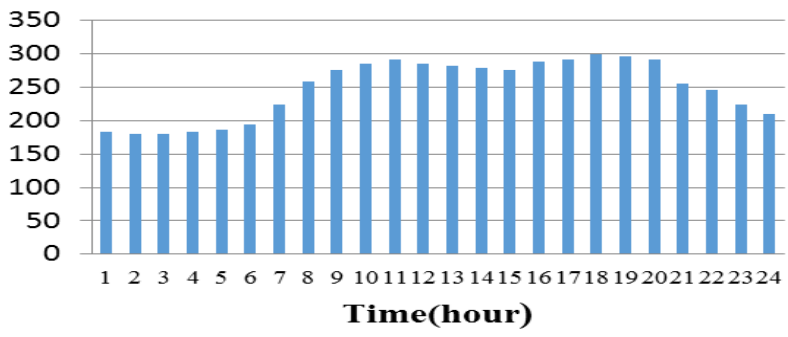

Figure 5. Forecasting curve for electrical demand 


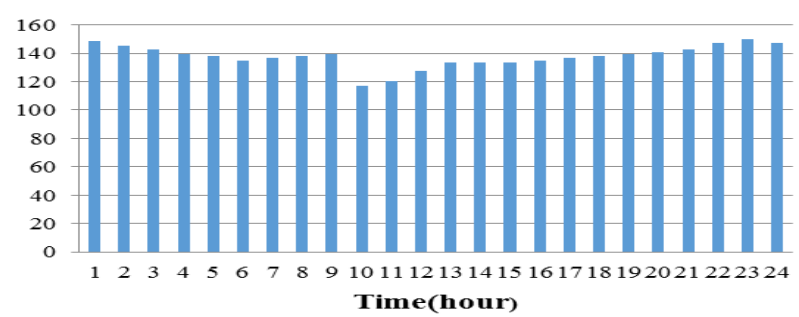

Figure 6. Forecasting curve for heat Demand.

For the sake of simplicity of the simulation, the four random variables were taken to go through uniform allocation with estimate values as predictable values of their allocation and especially, heat and electric loads subjected to uniform allocation with 0.1 for the variance; Wind energy and Photo-voltaic(PV) subject to evenallocation with the variation of $\pm 10 \%$ of the forecast values.Power(wind) and PV were subjected to the weather conditions. It is evident from the results that wind power fluctuates abruptly during the entire day, while PVsystem specially works during the daytime 10:00-17:00. It can be observed that there is complementary trend between the wind power and PV generation. In other words, it can be stated that wind power generation is huge in night time, while the $\mathrm{P}-\mathrm{V}$ generation is availableduring the day-hours. These different two graphs are used as forecast curve of Power(wind) and photo-voltaic (PV) in the model and ( mean value/ peak values ) is $54.26 \%, 25.36 \%$. Figure 5 and 6 show the forecast curve for heat demand andelectrical power demand. The CHP microgrid model was analyzed for various cases as follows.

Case I: In this case, the optimal scheduling is done by without considering peak value pricing so that excess power can be sold to main grid only. If generated power is less than electrical demand then power balance is made by the fuel cell and main grid. This power scheduling is implemented with improved PSO and the results have been comparedin Table 2. It has been shown in Figure 7 and 8 that improved particle swarm optimization provides the better result as compared to PSO and its other variants.

Table 2. Convergence results wihout considering peak-valley pricing

\begin{tabular}{|c|c|c|c|c|}
\hline Methods & $\begin{array}{l}\text { Best } \\
\text { Cost( }(¥)\end{array}$ & $\begin{array}{l}\text { Average } \\
\text { Cost( } ¥)\end{array}$ & $\begin{array}{l}\text { Standard } \\
\text { Deviation }\end{array}$ & $\begin{array}{l}\text { Avg.Time } \\
\text { (sec.) }\end{array}$ \\
\hline PSO & 1845.88 & 1859.63 & 10.7154 & 11.3 \\
\hline CSPSO & 1797.38 & 1847.35 & 19.0571 & 9.6 \\
\hline COPSO & 1783.77 & 1838.17 & 32.2825 & 11.7 \\
\hline IPSO & 1774.41 & 1822.56 & 31.5201 & 7.0 \\
\hline
\end{tabular}

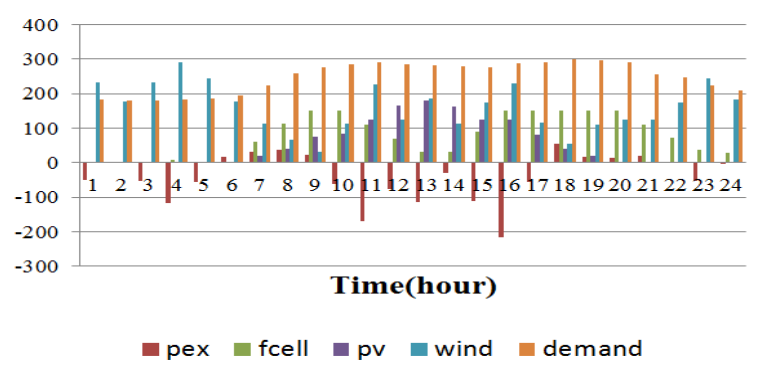

Figure 7. Optimum schedules for 24 hours using PSO

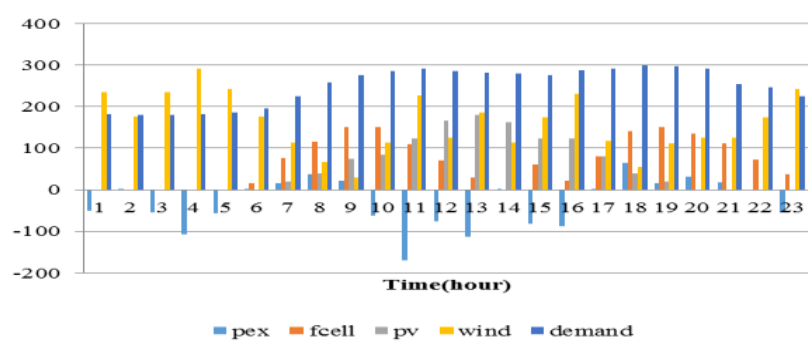

Figure 8. Optimum schedules for 24 hours using IPSO

Case II: In this case, peak valley pricing is considered. During peak period, CHP microgrid cannot meet the demand itself and hence, it must purchase power from main grid and electricity price is relatively high. During the intermediate and valley period, power demand is low. Therefore, CHP microgrid sells power to main grid and price is relatively low for this case. The optimum schedules are shown for 24 hours using PSO and IPSO algorithms in Figure 9 and 10 respectively. It can be noticed from Table 3thatpeak valley pricing cost of system is effectively reduced by using IPSO as compared to PSO and its variant.

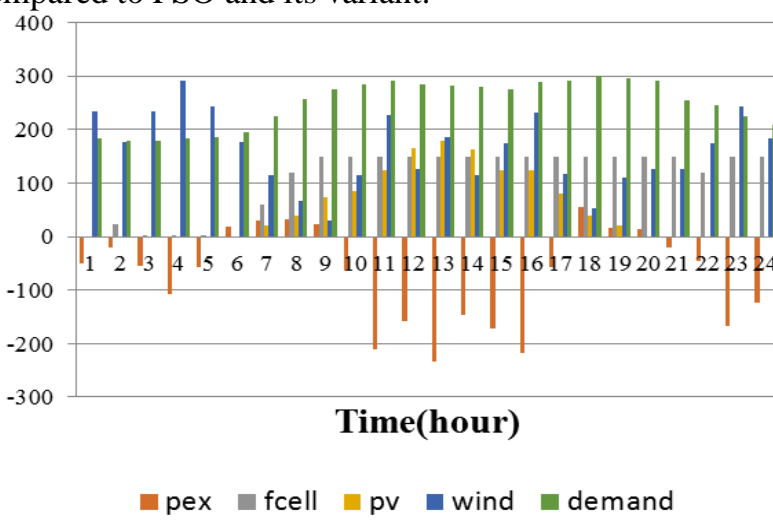

Figure 9. Optimum schedules for 24 hours using PSO considering peak valley pricing

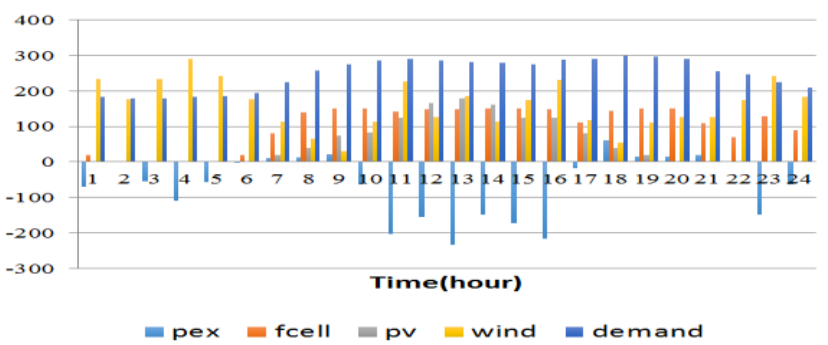

Figure 10. Optimum schedules for 24 hours using IPSO considering peak valley pricing

Table3. Convergence results using peak-valley pricing

\begin{tabular}{|c|c|c|c|c|}
\hline Methods & $\begin{array}{c}\text { Best } \\
\text { Cost( } ¥)\end{array}$ & $\begin{array}{c}\text { Average } \\
\text { Cost( } ¥)\end{array}$ & $\begin{array}{c}\text { Standard } \\
\text { Deviation }\end{array}$ & Avg.Time(sec.) \\
\hline PSO & 1518.019 & 1649.790 & 88.8017 & 17.8 \\
\hline CSPSO & 1567.816 & 1749.321 & 79.3883 & 12.4 \\
\hline IPSO & 1503.25 & 1652.260 & 62.6370 & 15.9 \\
\hline
\end{tabular}

Case III:In this case, peak load shifting is considered with fixed price and peak valley pricing. It is assumed that total power remain unchanged, while decreasing the power during peak period and increasing the power during the valley period by $10 \%$ each respectively.

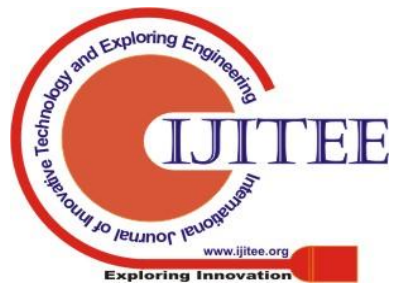


Owing to the fact that during valley period, power is in excess and selling price is low, while during peak period reverse happens. This method uses the resource effectively and reduces the operating cost of the microgrid. Figures 11 and 12 show the optimum schedules for 24 hours using PSO and IPSO respectively. The results have been depicted in Table 4 and 5 which show the superiority of proposed IPSO algorithm for finding the best and average cost. Table 4. Convergence results using peak load shifting and peak valley pricing

\begin{tabular}{|l|l|l|l|l|}
\hline Methods & $\begin{array}{l}\text { Best } \\
\text { Cost( }(¥)\end{array}$ & $\begin{array}{l}\text { Average } \\
\text { Cost( } ¥)\end{array}$ & $\begin{array}{l}\text { Standard } \\
\text { Deviation }\end{array}$ & $\begin{array}{l}\text { Avg.Time(sec. } \\
\text { ) }\end{array}$ \\
\hline PSO & 1752.041 & 1789.580 & 15.4581 & 4.0 \\
\hline CSPSO & 1749.129 & 1785.081 & 13.8532 & 3.4 \\
\hline IPSO & 1738.283 & 1781.603 & 27.6653 & 3.9 \\
\hline
\end{tabular}

Table 5. Convergence results using peak load shifting and peak valley pricing

\begin{tabular}{|l|l|l|l|l|}
\hline Methods & $\begin{array}{l}\text { Best } \\
\text { Cost( } ¥)\end{array}$ & $\begin{array}{l}\text { Average } \\
\text { Cost( } ¥)\end{array}$ & $\begin{array}{l}\text { Standard } \\
\text { Deviation }\end{array}$ & $\begin{array}{l}\text { Avg.Time(s } \\
\text { ec.) }\end{array}$ \\
\hline PSO & 1546.205 & 1622.687 & 40.1777 & 4.8 \\
\hline IPSO & 1441.380 & 1597.795 & 83.4773 & 12.5 \\
\hline
\end{tabular}

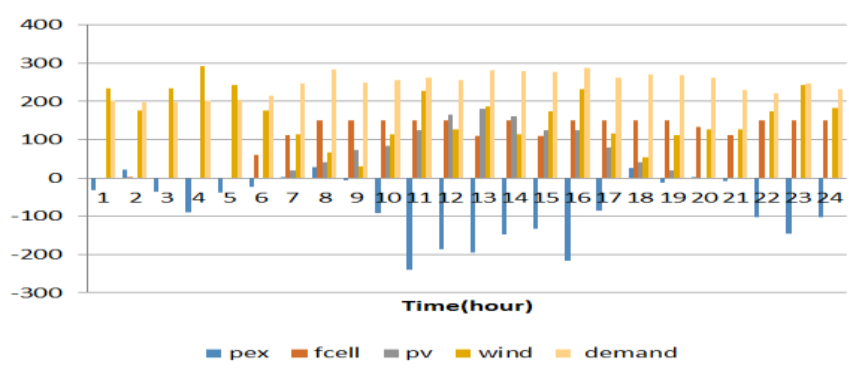

\section{Figure 11. Optimum schedules for 24 hour using PSO}

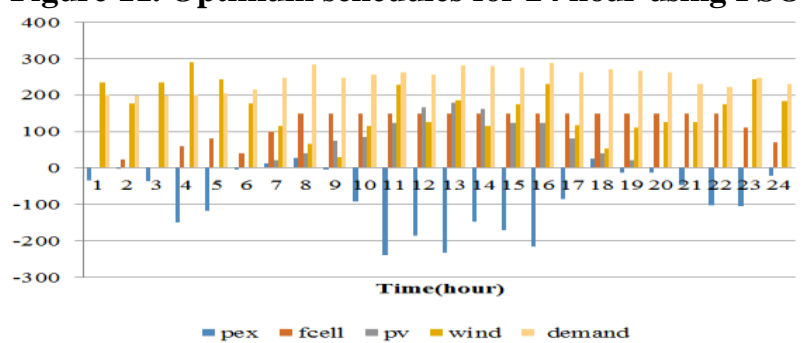

Figure 12. Optimum schedules for 24 hour using IPSO considering

\section{CONCLUSION}

In this paper, dynamic economic load dispatch problem of CHP microgrid comprising renewable resources (wind power and solar power), gas boiler, waste heat boiler, electrical and heating load was considered. Forecasted data of wind power, solar power, heat demand and electrical demand were used to predict the optimum schedule for next 24 hours using PSO and improved PSO algorithm. Accuracy and performance of improved PSO were measured by comparing the results with other optimization techniques. However, the CHP microgrid model considered in this paper has certain limitations, and its economic operation and optimization model needs further improvements using other fast algorithms to solve the model

\section{REFERENCES}

1. Xiaohong, X.zhanbo, J.qingshon, "Energy efficient building facilitated by microgrid",IEEE trans smart grid,vol.1,pp-243-52,2010

2. N.Hatziargyriou,H.asano,R.iravani, and C.Mamay,"microgrid"IEEE.powerenergy management,vol.5,pp.78-94,2007

3. F.Katiraei,R.iravani,N.hatziargyriou,A.dimeas,"microgrid management,"IEEE power Energy Mag.; vol. 6, pp. 54-65, 2008.

4. J. driesen and F. katiraei, "Design for distributed energy resources,'IEEE Power Energy Mag.,6:30-40,2008.

5. C. chen, S. duan, T. cai, B. liu, G. hu, "Smart energy management system for optimal microgrid economic operation," IET Renew Power Generation, vol.5, pp. 258-67, 2011.

6. A. J. lampiao, T. senjyu, and A. yona, "Control of an autonomous hybrid micro-grid as energy source for a small rural village," International Journal of Electrical and Computer Engineering (IJECE),vol. 7(1), pp. 86-99, 2017.

7. S. mirsaeidi, D. matsaid, M. wazir, H. habibuddin,K. ghaffari,"An analytical literature review of the available techniques for the protection of micro-grids," Int J Electr Power Energy Syst, vol. 58, pp. $300-06,2014$.

8. D. W. ross and K.sungkook,"Dynamic economic dispatch of generation,'IEEE Transa Power Ap Syst., vol. 99, pp. 2060-8,1980.

9. M.basu, "Dynamic economic emission dispatch using nondominated sorting genetic algorithm-II,". Int J Electr Power Energy System,vol. 30, pp. 140-9,2008.

10. P. attaviriyanupap, H. kita, E. tanaka, and J. hasegawa, "A hybrid EP and SQP for dynamic economic dispatch with nonsmooth fuel cost function,"IEEE Trans Power Syst., vol. 17, pp. 411-6,2002.

11. X. S. han, H. B. gooi, D.S. kirschen, "Dynamic economic dispatch: feasible and optimal solutions,"IEEE Trans Power Syst, vol.16, pp. 22-28,2001.

12. V. calderaro, G. conio, V. galdi, G. massa, Piccolo A., "Active management of renewable energy sources for maximizing power production,'Int J Electr Power Energy Syst, vol. 57, pp. 64-72,2014.

13. X. li, and C. jiang,"Short-term operation model and risk management for wind power penetrated system in electricity market,"IEEE Trans Power System, vol. 26, pp. 932-9, 2011.

14. K. Y. lee and M.A. El-sharkawi, "Modern Heuristic Optimization Techniques with Applications to Power Systems,'IEEE Power Engineering Society, Wiley-IEEE press, 2002.

15. Y. shi and R. C. eberhart, "Parameter selection in particle swarm optimization," in Proc. 7th Int. Conf. Evolutionary Programming, pp 591-600,1999.

16. Y. Shi and R.C. Eberhart, "Empirical study of particle swarm optimization," in Proc. 1999 Congr. Evolutionary Computation, 1999, pp.1945-1950.

17. M. shahverdi, and S.M.moghaddas-Tafreshi, "Operation Optimization of Fuel Cell Power Plant with New Method in Thermal Recovery Using Particle Swarm Algorithm," in proc. DRPT2008, April 2008, pp.2542-2547.

18. J.mitra, S. B.patra, S. J.ranade, "Reliability Stipulated Microgrid Architecture Using Particle Swarm Optimization," in proc. PMAPS2006, June 2006,pp.1-7.

19. L. liand B. liu, "Particle Swarm Optimization Algorithm”, 1st ed. Beijing, China: Metallurgical Industry Press, 2009.

20. DSNM rao and Niranjan Kumar, "Comparisionalinvestigation of load dispatch solutionswithtlbo," international journal of electrical and computer engineering (IJECE), vol. 7(6), pp. 3246-53, 2017.

21. P.K. hota and N.C. sahu, "Non-convex economic dispatch with prohibited operatingzones through gravitational search algorithm," international journal of electrical and computer engineering (IJECE), vol. 5(6), pp. 1234-44, 2015.

22. S.K.gachhayat et al. "Multi objective directed bee colony optimization for economic load dispatch with enhanced power demand and valve point loading,"'international journal of electrical and computer engineering (IJECE), vol. 7(5), pp. 2382-2391, 2017.

23. J. kennedy and R.C. eberhart, "Swarm Intelligence", 1st ed. Massachusetts, USA: Morgan Kaufmann Press, 2009.

24. J. kennedy and R. C. eberhart, "Particle swarm optimization," in proc. of IEEE international conference on neural networks, Nov/Dec 1995, pp.1942-1948. 
25. G. wang and S. he, "A quantitative study on detection and estimation of weak signals by using chaotic duffing oscillators," IEEE Trans. CircuitsSyst. I, Fundam. Theory Appl. 2003, vol. 50, no. 7, pp. 945-953.

26. R. caponetto, L. fortuna, S.fazzino and M. G. xibilia, "Chaotic sequences to improve the performance of evolutionary algorithms," IEEETrans. Evol. Computat., vol. 7, no. 3, pp. 289-304, 2003.

27. C. E. lin and G. L. viviani, "Hierarchical economic dispatch for piecewise quadratic cost functions," IEEE Trans. Power App. Syst., vol. PAS-103, pp. 1170-1175, 1984.

\section{AUTHORS PROFILE}

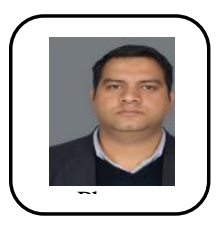

Surmadhur Pant is Assistant Professor Electrical and Electronics Department, Shivalik College of Engineering Dehradun,India.He has pursued B. Tech in Electrical Engineering from Uttar Pradesh Technical University, Lucknow and M. Tech. in Power System from Manav Bharti University Solan. His area of interest is renewable energy.

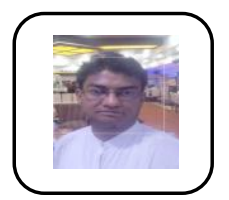

Dr.Vishal Gupta is a professor in ICFAI University Dehradun, India . 